\title{
The Euro Crisis. What Went Wrong with the Single European Currency?
}

\author{
Antonio Goucha Soares ${ }^{1,2}$ \\ ${ }^{1}$ ISEG_-School of Economics and Management, Technical University of Lisbon, Lisbon, Portugal; ${ }^{2}$ GHES Research Center, Lisbon, \\ Portugal. \\ Email: agsoares@iseg.utl.pt
}

Received June $14^{\text {th }}$, 2012; revised July $15^{\text {th }}$, 2012; accepted July $26^{\text {th }}, 2012$

\begin{abstract}
This article delivers a brief contribution to the debate about the Euro crisis. With that purpose it lists the objectives, interests and power relations underlined by the main political actors by the time of the introduction of monetary cooperation within the field of European construction. It begins with a reference to the first experiments of monetary cooperation between European countries - with the so-called European Snake, and later the European Monetary Systemwhich were intended to protect the common market from the turmoil caused by the collapse of the international monetary system. It also addresses the adoption of the economic and monetary union by the Treaty of Maastricht, the creation of the single currency and the first attempt to control fiscal policy with the Stability and Growth Pact. Then it concentrates on the crisis affecting the Eurozone, initiated with the Greek sovereign debt crisis. It starts with a reference to core Euro countries early reaction to the crisis, to continue with the measures adopted to support the Euro system, before discussing what would be the much needed firewalls that could deter financial attacks. The final sections are devoted to the Fiscal Treaty, and to the impact of crisis management on the European Union balance of powers.
\end{abstract}

Keywords: European Union; Monetary Integration; Single Currency; Euro; Euro Crisis; Fiscal Treaty; EU Balance of Powers

\section{Introduction}

The European Union has witnessed over the past two years the most serious crisis of its entire life. Although the word "crisis" is part of the genetic code of European construction, in the sense that were few periods over the past six decades that have not faced any form of crisis in the context of European integration, the fact is that the level of current events overcame all the worries and suspicions of the previous phases, to the point that some of the major European leaders admitted the break of old taboos, such as threatening a Member State to leave the Union.

On the basis of this situation is the crisis of the Euro. It should be remembered that the Economic and Monetary Union was until recently widely seen as one of the greatest achievements of European integration. By the time of its creation the European Commission considered that it represented the utmost form of economic integration. France, one of the partners of the so-called European integration engine, saw in the monetary union the way of countering the growing power that Germany would exert over the process of European construction. In turn, German Chancellor Kohl considered-by the time of na- tional reunification - that the adoption of the single currency was a matter of war and peace among European countries for the coming century [1].

Indeed, the major goal of European integration was to achieve a lasting peace within Europe, putting an end to the recurrent acrimony between the major continental powers. Since the very beginning the aim of European integration was to favor a harmonious atmosphere for the development of Franco-German relations. Thus, in the aftermath of the Second World War the European Economic Communities were the agreed device to overcome the political dichotomy framed by Thomas Mann, in favor of a European Germany.

This article intends to offer a brief contribution to the debate about the ongoing Euro crisis. With that purpose it lists the objectives, interests and power relations underlined by the main political actors by the time of the introduction of monetary cooperation within the field of European integration. It begins with a reference to the first experiments of monetary cooperation between European countries-with the so-called European Snake, and later the European Monetary System-which were intended to protect the common market from the turmoil 
caused by the collapse of the international monetary system. It also addresses the establishment of the economic and monetary union by the Treaty of Maastricht, the creation of the single currency and the first attempt to control fiscal policy with the Stability and Growth Pact.

The article then concentrates on the current crisis affecting the Eurozone, initiated with the Greek sovereign debt crisis. It starts with a reference to core Euro countries early reaction to the crisis, to continue with the measures adopted to support the Euro system, before discussing what would be the much needed firewalls that could deter financial attacks against the single currency. The final sections of the article are devoted to the latest Treaty adopted in the framework of monetary integration, the so-called Fiscal Treaty, and to the impact of crisis management on the whole European Union balance of powers.

\section{Monetary Cooperation}

The advent of monetary cooperation within the scope of European construction was a consequence of exchange rate volatility caused by the decline of the Bretton Woods system occurred since the late 1960s. The main concern of the Member States by adding a monetary dimension to European integration was to protect the common market from exchange rate instability of international financial markets, as well as to safeguard the financing of the common agricultural policy prices from the turmoil that could affect the exchange rate of different national currencies.

In the perspective of the European institutions, particularly the Commission, monetary integration would also represent the peak of a true European Economic Community, which was an additional reason to seize the opportunity created by the decomposition of the international monetary system and to relaunch the dynamics of European integration [2]. For these reasons, monetary integration appeared as a new strategic target that would serve both the interests of the Member States to ensure exchange rate stability, and the ideological purposes of European integration that inspired the action of the European Community institutions.

It should be remembered, however, that monetary policy remained by that time an exclusive national competence, and that the main concerns of the different Member States regarding this area tended to diverge. In fact, Germany intended primarily to curb the gradual appreciation of the Deutsch mark, which was increasingly seen as a strong currency in the international system, in order to maintain the competitiveness of its exports. Identical concerns guided the position of other countries with a strong currency-which had surpluses in its trade balance-such as the Netherlands [3].
In turn, the so-called weak currency countries-with trade deficits — such as France, Belgium, or even the UK, saw monetary cooperation as a key instrument for the success of its domestic policies against inflation. For these reasons, the division that initially emerged within Western Europe opposed this latter group of countries, which sought monetary cooperation-being called "monetarists"-against the strong currency states, which argued that monetary cooperation should be preceded by the harmonization of the economic policies of the Member States - for this reason referred as "economists" [2].

In the match between "economists" and "monetarists" countries (a term that had nothing to do with the economic theory of the same designation), the former argued that economic convergence must precede monetary integration, assuming the asymmetry of this process in the sense that the costs of exchange rate stabilization should be on countries with weak currencies, which should first improve economic data such as the level of inflation, interest rates and current accounts balance.

Instead, "monetarists" countries, supported by the Commission, felt that the costs of stabilizing exchange rates at the European level should be funded by countries with strong currencies, or that there should be at least some form of symmetry in the accommodation of those costs. In their opinion, surpluses countries should face a choice between financing the deficits of with weak currency countries, or accept higher inflation rates [1].

Thus, Germany argued since the very beginning of the process of monetary cooperation that the macroeconomic adjustment costs should be supported by weak currency countries, which should first reach the sustainability of its public finances and improve the competitiveness of their economies. It should be noted that since 1965 the German authorities expressed their concern that if the costs of economic adjustment were to stay on strong currency countries, this could generate a risk of moral hazard, passing a wrong message to weak currency countries that they could maintain high budget deficits, which would favor an indirect increase of inflation in Germany [3].

The divide between the two groups of countries was somewhat mitigated by the adoption of so-called Werner Report, in 1970, on the economic and monetary union. This document stated a new goal to be accomplished within ten years, passing through three distinct phases. The transition to the final phase would determine the irrevocable fixing of exchange rates between Member States, and the conferral of powers on monetary policy to the Union. The differences between Germany and France were the subject of a fragile compromise, which provided some parallelism between coordination of States economic policy and monetary integration [1].

However, the Werner Report suffered from the rapid 
deterioration of the international situation, due to the declaration of inconvertibility of the dollar vis-à-vis the ounce of gold. In an attempt to preserve exchange rate stability in Western Europe it was carried out an agreement on exchange rates in 1972, which became known as the Monetary Snake, aiming to contain the fluctuation of the national currencies of the contracting parties in a band of $2.25 \%$ [2].

This agreement, which also included the participation of the Scandinavian countries and the United Kingdom, faced some inconsistency regarding its Member States, due to several entries and exits of weak currency countries. Over time, the so-called Monetary Snake became a sort of enlarged area of the Deutsch mark, composed by countries aligned with the Bundesbank's monetary policy, a process that even saw France compelled to abandon the agreement in 1976, after some discontinuity in its implementation.

Note that the agreement on the Monetary Snake allowed Germany to curb the appreciation of its currency -by the time the Deutsch mark had already become a re- serve currency due to the international monetary system breakdown-without having undergone any constraints from third countries in running its monetary policy [1].

\section{The European Monetary System}

A further attempt to overcome the divide between the two groups of countries in the area of monetary cooperation came from Roy Jenkins, in 1977. The President of the European Commission launched the idea of creating a European Monetary System, which would be developed by German Chancellor Schmidt, in line with French President Giscard d'Estaing. The political agreement for the creation of the new system was concluded in 1979 and achieved a Franco-German settlement concerning the main goal of defending exchange rate stability within the European Community [4].

The European Monetary System was based on the mechanism of the Monetary Snake, which aimed to promote exchange rate stability. The EMS reintroduced a limit to the fluctuation of national currencies, limited by a band of maximum variation of $2.25 \%$, with the exception of the Italian lira that could float up to $6 \%$. The novelty of the mechanism was the introduction of a new currency - the so-called European Currency Unit (ECU) - which established a benchmark for each national currency [2].

It is worth remembering that Helmut Schmidt led personally the process that led to the agreement on the European Monetary System to prevent leaks to the technocratic circles, notably the national central banks, fearing eventual obstacles that could be raised by the Bun- desbank [3]. In other words, although monetary cooperation was an area characterized by the strong technical nature of its contents, Schmidt sought to affirm the political aim of the system.

In political terms, the European Monetary System was the first initiative of German leadership within the process of European integration. Until then, the European political agenda was dominated by France or at spaces at the initiative of the Community institutions, particularly the Commission. The fact that they took the area of monetary cooperation for a premier on European political leadership is symptomatic of the importance that this area represented for Germany.

Indeed, the aim of exchange rate stability that presided over the European Monetary System assumed the convergence of the economies of the contracting countries, especially in the effort to combat inflation, which was a fundamental priority for the German government. Germany also wanted to protect against the negative effects of international monetary volatility, in particular the appreciation of the Deutsch mark as a reserve currency. France and Italy saw the participation in the system as an instrument for the implementation of its domestic policies to fight inflation [1].

During the negotiations for the creation of the European Monetary System the discussions about who should bear the costs of adjustment in times of crisis reemerged, with Germany arguing that it should be supported by weak currency countries, and France, Belgium and Italy aiming to introduce a less asymmetric model for the distribution of those costs, which would implied the creation of mechanisms that allow the financing of deficit countries.

The idea of creating a European Monetary Fund, which appeared in the first Schmidt draft, was replaced by a monetary cooperation fund that could provide shortterm loans to countries with liquidity problems. However, there were rare cases of the stability mechanism action, to the extent that international markets provided funding to needed countries without the constraints arising from the conditionality of the monetary cooperation fund [3].

Overall, it can be said that the European Monetary System helped to achieve a zone of monetary stability among its contracting States for more than a decade, with stabilization of exchange rates and inflation [1]. However, during the first years of its implementation the system went through some tensions due to currency devaluations of the French franc in the early ages of the Mitterrand presidency.

Indeed, the French franc exchange rate readjustments in the first half of the 1980s were made only after lengthy negotiations with the German government, which in turn demanded France to increase taxation and reduce public expenditure, a set of duties that led some commentators 
to ponder whether the European Monetary System could be viewed as a light version of the International Monetary Fund [3].

\section{The Economic and Monetary Union}

The aim of an economic and monetary union was reintroduced on the European agenda by the Commission President Delors. Although monetary union had been its initial preference in 1985, Jacques Delors-who had been minister of finance during the first governments of the Mitterrand presidency—soon realized that he could not obtain the consensus of all Member States to achieve such a purpose.

Hence, he began by gathering the support of the Member States for the internal market program. After the coming into force of the Single European Act, Delors returned to its idea of monetary integration, presenting the goal of an economic and monetary union as the corollary of the single market, to the extent that this implied the complete liberalization of capital movements [5].

Although he got the so-called Delors Report on the Economic and Monetary Union to be approved by the European Council in 1989—a paper prepared by a working group composed by the governors of national central banks-its achievement remained doubtful due to the British intransigence, and above all the very hostility to the idea of a single currency raised within Germany, in particular, the Bundesbank. In fact, Germany was the main beneficiary of exchange rate stability provided by the European Monetary System, and the road towards a monetary union would imply the loss of sovereignty in the area of monetary policy.

A vital issue in the decision to establish an economic and monetary union was the fall of the Berlin Wall. Indeed, the sudden evolution of the process of German reunification-presented to the other European Community Member States as a fait accompli, by Chancellor Kohl-provided a new interest to the creation of an economic and monetary union, particularly by France, which had strong worries about the consequences of German reunification in the European balance of powers.

For these reasons, France required that Germany should give a clear signal about the sound nature of its European commitments. Therefore, Germany had to come to terms and accept the move for an economic and monetary union, in line with the Delors Report [5].

Indeed, apart from involving the new Germany in a lasting way with the European institutions, France also wanted Germany to suffer a real loss in an area in which it had been able to assert its leadership within Europe: monetary policy. So the opportunity to create an economic and monetary union, endowed with a single currency, was the most appropriate tool to ask Germany to renounce to the symbol of its economic hegemony across Europe, the Deutsch mark. As mentioned above, Germany had ruled over European monetary policy throughout the previous decades, controlling the Monetary Snake, and the European Monetary System.

Germany raised some conditions to accept the call for an intergovernmental conference to establish an economic and monetary union. On the one hand, it asked that the economic and monetary union should be completed with an evolution to a political union. On the other hand, it wanted to control the adoption of the technical criteria that would pave the way for the creation of a single currency.

\subsection{The Single European Currency}

The intergovernmental conference on the European political union delivered results that fell short of the expectations created when it was convened in 1990. The European Union established by the Maastricht Treaty did not embody the goals of political integration that inspired some European leaders such as Chancellor Kohl.

The minimalist content of the European political union was reflected by the intergovernmental conference on the economic and monetary union. In fact, the conference mainly discussed a set of technical issues - the major guidelines were already set by the Delors Report—with a background opposition between the German positions, and those presented by the Commission and France. Overall, Germany was able to see their claims reproduced in the final negotiations draft, from the start to be the country with the biggest lost due to the creation of the single currency, so it would be one that would face more problems at the domestic level to approve the agreement on the economic and monetary union.

Hence, regarding the major issues discussed during the negotiations on the economic and monetary union Germany obtained the acceptance of their positions on the whole core of nuclear questions, namely the convergence criteria, the European Central Bank's independence, the scope of application of so-called opting-out, the schedule for the transitional period with the possibility of a twotier system, the provisional nature of the entities created during the second phase, the headquarters of the central bank, the designation of the single currency, and the ban on bailing-out highly indebted countries [3].

The only issue that did not deserve immediate acceptance of the German positions during the Maastricht negotiations concerned the instruments of control and sanction of countries with excessive budget deficits, which were later incorporated by the Stability and Growth Pact.

It is important to note that the core issues discussed during the intergovernmental conference concerned the monetary union. Indeed, the Maastricht Treaty kept eco- 
nomic policy in the field of national competence. Hence, it created a structural imbalance in the working of the economic and monetary union: monetary policy became an exclusive competence of the European Union, according to article 3 of the Treaty on the Functioning of the European Union; economic policy remained within the jurisdiction of the Member States, according to article 5(2) of the Treaty on the European Union. ${ }^{1}$

Indeed, the Maastricht Treaty established a centralized monetary policy, whose implementation was conferred to a full independent institution, the European Central Bank. However, the monetary union was to be built within a truly decentralized political system, in so far as it still depends on the unanimous agreement of the Member States. That is to say that the Euro should operate without a strong political power in the background-despite the question of statehood-which could define economic guidelines to support the running of monetary policy [5].

Similarly, the monetary union was not complemented by a qualitative conferral of powers that would allow, for example, supporting countries that could face some liquidity problems. Rather, the Maastricht Treaty enacted a ban on the bailout of the Member States, as well as the interdiction of financial assistance from the European Central Bank to national governments. Hence, the Economic and Monetary Union kept the asymmetric nature underlying monetary cooperation agreements concluded in the previous decades, compelling deficit countries to support the costs of adjustment in times of economic crisis or financial turmoil.

\subsection{The Stability and Growth Pact}

The Amsterdam Treaty, which had been drafted with the purpose of completing the political process initiated with the Maastricht Treaty, gave some impetus to the political dimension of the European Union. However, as far as the Economic and Monetary Union was concerned, its contribution was restricted to the Stability and Growth Pact, which fulfilled a German claim that had not been held in Maastricht. Thus, the conferral of budgetary powers to the European Union was confined to a system of centralized control of fiscal policy to deal with profligate Member States, through a set of mechanisms for monitoring and sanctioning Euro countries with large public deficits. Rather, the monetary union remained devoid of any budgetary instruments - as well as the financial resources - that would allow playing a stabilizing role.

The Stability and Growth Pact had its baptism of fire in the early years of the new century. The difficulties that the economies of some Euro countries then faced caused a surge on government spending and a decrease on tax payments. Consequently, France, Germany, Italy and

\footnotetext{
${ }^{1}$ See also article 5(1) of Treaty on the Functioning of the European Union.
}

Portugal breached the 3\% limit that the Pact stipulated for the budget deficit, leading the Commission to open an excessive deficit procedure. Reiterated breaches of the Stability Pact provisions by the three last-mentioned Member States led the Commission to continue the procedure, and to submit to the Council a proposal to adopt the sanctions laid down in the EU Regulation that implemented the Stability Pact.

However, in late 2003 the Council refused the Commission proposal and decided to give the countries concerned more time to carry out fiscal adjustment, without the constraint of the proposed fines. The Commission appealed from the Council's decision to the European Court of Justice, which delivered a quite formalist judgment, allowing national governments in practice to ignore Commission recommendations. ${ }^{2}$ Thus, Member States weakened the binding nature of the Stability Pact, in deciding not to apply sanctions to the country that shown more conviction in its creation [6].

\section{The Euro Crisis}

The outbreak of the sovereign debt crisis within the Eurozone in 2010 exposed in a painful way the structural weaknesses of the constitutional framework governing the Economic and Monetary Union. First of all, the lack of a true European political union that could favor effecttive solidarity between Member States. Furthermore, the nonexistence of stability mechanisms to provide support to countries that could face liquidity problems.

In fact, the Maastricht Treaty did not contain any provisions to deal in case a Eurozone solvent country would suffer speculative attacks affecting its financial liquidity. Besides, the Euro countries face the difficulty of having to issue its sovereign bonds in a currency which they do not control, in the same way of a foreign currency. Thus, the lack of an effective liquidity crisis management mechanism within the Eurozone allow for the financial markets to force the default of an Euro country through speculative attacks on the issuance of government bonds, turning a liquidity crisis in a problem that could put into question the solvency of the State itself [7].

The reason for this legal gap in the Maastricht Treaty was the need to prevent moral hazard from profligate Member States, forcing those governments to implement the rules on fiscal discipline. In case a Euro country would fail to access markets for financial needs, the alternative would be to restructure its debt or, more likely, to ask financial assistance from the International Monetary Fund. One could not rule out the prospect of the Eurozone countries to adopt, in extreme circumstances, some device aimed at providing financial support [8].

Notwithstanding the weaknesses of the Monetary Un-

${ }^{2}$ Case C-27/04, Commission v. Council, 13 July 2004. 
ion-resulting from the constraints surrounding its creation by the Maastricht Treaty and the subsequent evolution of the political process of the Union-it seems clear that the leading Eurozone countries showed unusual difficulty to understand the deep nature of sovereign debt crisis when it first arrived in 2010.

Essentially, the northern countries initially refused the existence of a systemic crisis affecting the Monetary Union, whose vulnerabilities were being exploited by financial markets, preferring to stress the individual responsibility of the Member States that faced difficulties in issuing sovereign bonds, pointing out its excessive budget deficits in breach of the Stability Pact.

Although the sovereign debt crisis of the Eurozone countries has shown the risk of contagion to other countries from the beginning, and to the single currency as a whole, the response of the major States preferred to point out the ethical behavior of the countries. Thus, instead of promoting the adoption of substantive measures that could deter speculation against countries affected by a lack of financial liquidity, Germany chose to emphasize the need for those countries to take hard fiscal austerity plans. If not so, according to the German perspective, the Eurozone would consent the moral hazard caused by fiscal laxity of the affected nations, allowing for a transfer of the costs of stabilization between the Euro area countries.

At the end of the day, Germany kept its position taken since the beginning of the process of monetary cooperation, concerning the issue of who should bear the costs of adjustment in case of financial turmoil. Likewise, Germany conserved the ethical foundation of its thesis, set out in the 1960s, whereas the delivery of financial assistance to States in difficulty could increase the danger of moral hazard, which would result in a benefit to the countries that breached the Stability Pact rules.

The German position would be praiseworthy for its consistency in case the survival of the Euro itself has not been undermined by the contagion of the sovereign debt crisis to a growing number of countries-a reality that became clear throughout 2011-along with the failure of the European Union to take adequate decisions and to provide financial solutions to overcome the systemic crisis that hit the single currency.

\subsection{The Euro Answer}

Nevertheless, it should be recognized that Germany made some concessions in favor of the preservation of the Euro. It should be remembered, indeed, that Germany has been the main beneficiary of the elimination of ex- change rate risk provided by the Euro in intra-European trade, beyond the fact that the Monetary Union has favored its exports to third countries by avoiding the overvaluation of the European currency [9]. Those concessions were tempered, however, with the request for stronger control over Euro countries fiscal policy.

Thus, faced with the threat of a Greek default — and the consequences that this could imply for the Euro areaGermany accepted the creation of stability instruments with a view to provide financial support to countries in difficulty. ${ }^{3}$ Moreover, the contagion of the sovereign debt crisis to other Euro countries led to the adoption of a European bailout mechanism on a permanent basis-the European Stability Mechanism ${ }^{4}$ - a case that required a revision of the Treaty on the Functioning of the European Union to allow the institutionalization of this new device of greater European responsibility.

However, the debate on the scope of financial means allocated to affected countries revealed Germany's doubts to adopt the adequate measures that would allow a serious response against market speculation. Indeed, the scarcity of financial resources allocated to the European bailout funds was fueling fears among investors about the effectiveness of those instruments in case a big Euro country would face liquidity problems. Thus, if the contagion of the sovereign debt crisis should extend to countries like Italy or Spain, the amount of money allocated to the European bailout mechanisms would not suffice to face the financial needs of these countries.

The lack of market trust in a European response to the sovereign debt crisis would increase with Chancellor Merkel idea, presented in October 2010 after a meeting with President Sarkozy, to involve private investors in an eventual restructuring of the public debt of countries under financial assistance programs. If by then the crisis of sovereign debt was restrained to countries with high public debt levels, the threat of private sector involvement was the fuse for the spread of the sovereign debt crisis, whose next target was Portugal, forced to ask for financial assistance in the spring of 2011. Indeed, the prospect that private institutional investors could suffer major losses with sovereign bonds of peripheral Eurozone countries increased the risk of lending money to those nations, with a consequent boost of interest rates in financial markets.

In addition to traditional German political stances on monetary policy-which argued that adjustment costs

${ }^{3}$ The European Financial Stability Facility (EFSF) is a special purpose vehicle financed by members of the Eurozone to address the European sovereign-debt crisis. It was agreed on May 2010, and is authorized to borrow up to $€ 440$ billion. There is also the European Financial Stabilization Mechanism (EFSM), an emergency funding program reliant upon funds raised on the financial markets and guaranteed by the European Commission. The Commission fund, backed by all 27 European Union members, is allowed to raise up to $€ 60$ billion. The EFSM has been operational since May 2010. The EFSF and the EFSM are both temporary bailout funds.

${ }^{4}$ The Treaty on the European Stability Mechanism was signed on February 2012. 
should be supported by deficit countries, as well as the need to promote sustainability of public finances-there was another issue that served as backdrop to the positions taken by Merkel at the beginning of the Euro crisis: the managing of the domestic electoral cycle. In fact, during 2011 several German Landers went through regional elections, which made the Chancellor's political agenda to concentrate more on domestic issues than on European politics. Faced with a public opinion that showed a growing skepticism concerning the financial assistance provided to Euro countries affected by the sovereign debt crisis, and a tabloid press that questioned whether the Germans should support the lifestyle and the profligate vices of the Euro periphery, Merkel preferred to keep a minimalist approach in the European front, not to undermine the coming domestic elections. For these reasons, she began to resist the delivery of financial support to countries in difficulty, and then to proceed with a policy of underfunding the European bailout mechanisms, to conclude with the idea of involving private sector investtors in an eventual Euro countries' haircut. Hence, in the making of the German position during the first year of the Euro crisis, domestic preferences related to the electoral cycle overlapped the Europe's vital interest of a rapid resolution of the problems affecting the monetary union.

Alongside with the devices adopted for the financial bailout of Euro countries, the crisis has also led the European Union to strengthen mechanisms for fiscal discipline in the context of a legislative package-the sixpack-aimed at improving the economic governance of the single currency. ${ }^{5}$ Thus, there was an increase of European supervision over fiscal policy, to allow a consistent and timely implementation of measures. In addition, it was approved the so-called European semester, which provides for a preliminary exam of the national draft budgets guidelines by the European institutions, in order to ensure its compliance with the stability programs presented by each Member State.

However, the core of the six-pack concerned the reinforcement of sanctions, predicting that countries that refuse to fix limits for budget deficit and government debt will be submitted to quasi automatic fines proposed by the Commission, unless the Council decides to refuse its application by qualified majority. Thus, with the sixpack the Union sought to meet the objections raised by those who believed that the sovereign debt crisis would have resulted from lax fiscal policy in the countries of the Euro periphery. Therefore, strengthening fiscal policy

\footnotetext{
${ }^{5}$ The six-pack is composed by five regulations and one directive and entered into force on December 2011. It applies to all Member States, but with some specific rules for the Euro countries, especially regarding financial sanctions. The six-pack does not only cover fiscal supervision, but also macroeconomic surveillance under a new macroeconomic imbalance procedure.
}

centralized control.

Despite the wide range of measures taken since the dawn of the sovereign debt crisis, and the permanent alert that Europe has experienced since then, it is true that this did not prevent the risk of contagion to other Member States, namely, to the larger economies of Spain and Italy. At the root of the risk of contagion seems to be the inability of the Eurozone countries to agree on a credible bailout program for the nations in difficulty. In particular, to gather a larger amount of funding adequate to cool fears of institutional investors, and create a stronger firewall against financial speculators attacks.

\subsection{Potential Euro Firewalls}

In the absence of compelling bailout funds-endowed with a deterrent firepower against speculative attacks to the Eurozone-there have been put forward other alternatives to overcome the Euro crisis allowing for more European responsibility. Among them the issue of Eurobonds by the European Union, or allowing the European Central Bank to act as a lender of last resort within the Euro area, were those considered that could put an end to the turmoil threatening the survival of the single currency.

The idea of creating Eurobonds would allow for a joint responsibility of the Euro countries for the issuance of sovereign debt within the Monetary Union. In political terms, Eurobonds would represent the adding of a mutual guarantee on the Euro countries' debt [8]. From a legal standpoint, the creation of this sort of European debt would require a revision of Article 125 of the Treaty on the Functioning of the European Union which prohibits the existence of any kind of liability-from the Union or from the Member States-with the commitments taken by the governments of other countries, i.e., the prohibittion of the so-called bailout of the Member States.

By the end of 2011 the European Commission presented a report on the possible creation of so-called Eurobonds, referring it as stability bonds, which drew different scenarios for the issue of these bonds. The main objective would be to ensure access to international markets for all countries in the Eurozone, at reasonable interest rates. The Commission distinguished between different models of Eurobonds, providing either the issuance of common total debt of Eurozone countries, with full joint guarantee of all Member States, or a partial issuance of the debt of the States, up to a percentage of the gross domestic product of each country with the joint guarantee of all states up to this limit-the so-called blue bonds, unlike the remaining national debt which should be issued at higher interest rates, or the red bonds. Apart from these two models, the Commission also established a third kind that was the common issue of the debt of 
countries in difficulty, but without joint guarantee from other Member States. In the latter case, as it did not involve any form of liability from other Euro countries, it would not be necessary to amend the referred provision of the Treaty.

Beyond the fact that they could work as remedy against the deadly crisis of the Euro, Eurobonds could provide other benefits for the functioning of the European debt market by the effect of scale they would generate. In fact, European countries could create a bond market with the same size as the United States, and higher than Japan, countries with similar problems in terms of sustainability of public finances, but which manage to be financed by international markets at lower rates than the Eurozone countries.

The German reaction to the Commission's study on Eurobonds did not take long. Indeed, Chancellor Merkel reacted to the Commission draft considering the creation of Eurobonds as a very disturbing and inappropriate scenario because they would allow for mutualizing Euro area countries' government debt, a case which did not solve the crisis. In Germany's view, the creation of Eurobonds would determine a union of transfers within the single currency, making German taxpayers to bear the costs of financing other Euro countries.

Another strategy regarded with a potential deterrent effect against speculative attacks to the Eurozone countries would be to allow the European Central Bank to act as lender of last resort. Indeed, the main problem affecting the existing European bailout funds lies on scarce allocation of financial means, namely if they have to assist larger economies such as Italy or Spain. With the recognition of such a function to the European Central Bank the problem would have been solved because this institution has potential unlimited financial resources, since it holds the exclusive right to authorize the issue of banknotes within the Eurozone, according to Article 128 of the Treaty on the Functioning of European Union. Thus, conferring the European Central Bank the role of lender of last resort within the Eurozone would eliminate the financial markets fears regarding an eventual default of Euro countries that face liquidity problems [7].

This solution raises some difficulties within the European Union, mainly from a legal perspective. In fact, Article 123 of the Treaty on the Functioning of the European Union prohibits direct purchase of government bonds by the European Central Bank. That is to say, the European Central Bank can not intervene in the so-called primary market debt of the Eurozone countries. However, this institution may purchase those bonds in so-called secondary market, a situation that has been taking place since 2010 with the acquisition of securities from Greece and Portugal, and later from Spain and Italy.

Beyond these legal hurdles, which would require the amendment of a Treaty provision, conferring this task to the European Central Bank also raises some ideological issues. Indeed, Germany feared that this could create a roar in the monetization of the Euro countries debt, with risk of increased inflation [7]. On the other hand, it was also concerned that by assigning this role to the European Central Bank-like the U.S. Federal Reserve, or the Central Bank of the United Kingdom, which go to financial markets to purchase their own sovereign bonds-it could send a negative signal to the Euro periphery, with risk of moral hazard regarding the break of fiscal discipline within the Monetary Union [8].

\section{The Fiscal Treaty}

The worsening state of the whole Euro area from the fall of 2011-with a risk of contagion of sovereign debt crisis to Italy and Spain, the Greek debt haircut and the adoption of a second bailout for this country, the decrease of the financial rating of several Euro countriesled the Euro crisis to enter into a new phase with unprecedented contours. In fact, several major political actors of the European Union, as Mr. Sarkozy or the President of the European Central Bank, even admitted the chance of the end of the Euro. Given the drama atmosphere lived in the Monetary Union, in which has not missed a threat of expulsion of Greece from the Eurozone by Mrs. Merkel [9], the idea to create a Fiscal Union gained momentum, which would require an amendment to the Treaties.

In this context, there were great expectations regarding the measures that the December European Council summit would take to overcome the Euro crisis. There was a wide consensus on the diagnosis of the crisis: the failure of the Union to adopt a credible bailout system to assist weaker Member States. The therapy for the weakness of the Monetary Union could pass, in turn, by adopting one of following alternatives: a significant increase on the financial means allocated to the European Stability Mechanism; the issuance of Eurobonds; the prospect of the Bank Central European to act as lender of last resort for countries in financial need.

In the background of the negotiations were the German demands for a further increase of fiscal discipline for Eurozone countries, along with the strength of control mechanisms by European institutions, and the adoption of semi-automatic sanctions to the States that breached fiscal policy rules. Given the feared collapse of the Euro it would be expected if Mrs. Merkel obtained full approval on the requests of German financial orthodoxy by her Eurozone partners, this would allay domestic fears in Germany about fiscal reliability of the Euro periphery countries and, as a result, it would favor a political deal to endow the Euro with a strong firewall to fight against 
speculative attacks on international markets. That is to say it would allow reaching a reasonable balance between principles of fiscal policy centralized control and of greater European responsibility.

Despite the fragility of the situation, the European Council decided to carry out a new intergovernmental treaty-without the agreement of the United Kingdom and the Czech Republic-with the goal to establish a Fiscal Compact. The political agreement reached with the Treaty introduces the principle of States balanced budgets, with a new structural deficit limit of $0.5 \%$ of the gross domestic product-which should be introduced into their national legal systems-complemented by an automatic correction mechanism that shall be triggered in the event of deviation; it constrains countries with excessive deficit procedure to a long lasting adjustment program, carried out under European control; it provides for the automaticity of the sanctions proposed by the Com mission; and a mechanism will be put in place for the ex-ante reporting by Member States of their national debt issuance plans. ${ }^{6}$

Thus, the Fiscal Treaty acknowledged the German requests of strict fiscal discipline, which will be attached with the strengthening of European control and completed by the automaticity of sanctions. Out of the agreement remained what was expected to be the price that Member States paid for having accepted the rules that embody German financial orthodoxy in the working of the Monetary Union, i.e., to provide the Eurozone with a deterrent firewall against speculative attacks to the most vulnerable countries. Therefore, the Fiscal Treaty represents a clear mark of German hegemony within the Union, in the sense this country was able to defend its global interests, as well as to make the others accommodating to the whole set of its preferences in the functioning of the Euro.

\section{The New EU Balance of Powers}

The Euro crisis, and the way it has been approached over time, had also a profound effect at the institutional level. Indeed, the Euro crisis has been managed since its inception by the European Council, which met with such an unprecedented frequency that trivialized the summits of EU heads of government. If in the past the European summits were quite uncommon events, restrained to four annual meetings, with the Euro turmoil became almost a monthly happening, which allowed the Member States to assume directly the management of the crisis. In contrast, the Union institutions were apparently removed from the European stage. Therefore, the Euro crisis has strengthened the intergovernmental nature of the Union with the

${ }^{6}$ The Fiscal Treaty was signed on March 2012, officially named as the Treaty on Stability, Coordination and Governance in the Economic and Monetary Union.
European Council playing the role of an economic government.

However, and despite the preeminence of the European Council in the working of the Union, the Euro crisis revealed a most disturbing reality, namely, the existence of a true European political directorate. Indeed, European summits were preceded, invariably, by bilateral meetings between the German Chancellor and the French President, in which they agreed strategies to present to their Union colleagues. Hence, the meetings of the Franco-German axis conditioned the European Council conclusions insofar it shaped the debate between heads of government to the positions and interests predetermined by the major Eurozone powers. Moreover, the long-lasting of the crisis has highlighted the growing subordination of France to the German positions, with the first being unable to counter, or even deter, the orthodoxy of the solutions advocated by Chancellor Merkel. ${ }^{7}$ Thus, the Euro crisis favored the unchallenged assertion of a German hegemony in the European Union [10].

In institutional terms, one of the main victims of the Euro crisis was the European Commission. The institution that according to the Treaties represents the general interest of the Union was relegated to a secondary role during the financial turmoil that hit the Euro. In the past, the Commission had always acted as a counterweight to the influence of the Member States, in particular the most powerful ones. It was, therefore, the institution in which smaller countries identified more because it was able to provide a protective shield against the hegemony of the big Member States. During the Euro crisis, the big countries took the lead in the political process in a blatant way relegating the other States to an almost ritual role of taking their seat at the European Council meetings, and giving their approval to prearranged solutions adopted by the Franco-German axis. Meanwhile, the Commission seemed to fit with the new soul that crossed the European Council, being unable to take the initiative for alternative solutions and accommodated to the priorities presented by the most powerful, to the detriment of the general interest of the Union in overcoming the Euro crisis soon.

Beyond the Commission, the European Parliament was the other institution deeply affected by the Euro crisis. It should be remembered that Parliament was the institution that gained more political power across the constitutional changes that took place in the Union during the last 20 years. With the Lisbon Treaty, the Parliament became an institution with wide budgetary and legislative powers, in addition to the political control over the Commission.

\footnotetext{
${ }^{7}$ The election of a new President in France, François Hollande, which defeated former President Sarkozy in May 2012, seems to pave the way for a more balanced relationship between France and Germany. Indeed, during the 20th European Summit devoted to the Euro crisis, in June 2012, France supported claims presented by Italy and Spain, making Chancellor Merkel to come to terms.
} 
Therefore, the Parliament must be regarded as a crucial institution in the political process of the Union.

However, the European Parliament passed almost unnoticed throughout the whole period of crisis that hit the Monetary Union. If it is true that some of the affected areas were located within the jurisdiction of the Member States, which would prevent the action of the European Parliament, it is also a fact that the European Parliament has never been able to appeal the attention of the media as the main political forum of debate on European issues and to influence the Union's political agenda through its initiatives. A parliamentary institution that proves not to be able to act as representative of the democratic legitimacy resulting from the direct vote of the citizens, and attract the attention of the European public opinion during the greatest crisis of European integration, can hardly aspire to be the center of the political process and be the major source of legitimacy in a further stage of a European Political Union.

Thus, it can be stated that despite its legislative job in the adoption of the six pack to strengthen fiscal discipline of the Member States, the European Parliament has been relegated to a marginal role during the Euro crisis. In this way one can understand Helmut Schmidt urging to the current President of the European Parliament for the institution to be able to make its voice across the European public space, in order to have some influence in the path to overcoming the crisis [11]. Otherwise, the unbearable lightness of his behavior during the Euro crisis risks downgrading it to a level of political irrelevance.

Still, and in political terms, the Euro crisis may have added a positive side to the functioning of the European Union. Certainly, the crisis of the single currency had the effect of introducing one of the darkest areas of European construction in the public debate: monetary integration. Indeed, since the late 1960s that this area had been the subject of monetary cooperation within the framework of the European Communities. However, the scope of discussion was restricted to slim technical elite, controlled by those who were responsible for monetary policy at the national level. Thus, the opacity of the field of monetary cooperation through the entire period the so-called Monetary Snake as well as the European Monetary System. Likewise, the negotiations on the Economic and Monetary Union passed almost unnoticed from the publicthey were controlled by the leaders of national central banks-in contrast to what happened in the intergovernmental conference on the political union.

With the advent of the sovereign debt crisis and its evolution to a crisis of the Euro system, the Monetary Union gained unprecedented visibility in the European public sphere. In fact, it became an issue of wide public discussion, beyond the inner circle of the technocratic elite that dominated monetary theories and the financial jargon. For those reasons, monetary integration has acquired prime time standing within the European political issues, and this allowed the public opinion of the States to acquire a better knowledge of the interests at stake, the costs and benefits of the single currency, the national preferences and the balance of powers underlying the decisions taken in the Eurozone. Mainly, the Euro crisis will have the merit to increase the level of transparency in the debate on monetary issues, clearly showing who has the leading power, in real terms, within the European Union.

\section{Conclusions}

Since the 1960s there was a European cleavage in the area of monetary affairs between deficit countries and strong currency nations. The former were leaded by France, and the latter were under German guidance. The fact that by the time the Deutsche mark had become a reserve currency in international terms, allowed Germany to set the rules to the different experiments of European monetary cooperation that took place after the decline of the Bretton Woods system, such as the Monetary Snake and the European Monetary System.

With the end of the cold war, France wanted Germany to show a clear European commitment in order to agree with its fast process of national reunification. The result was the decision to move from currency cooperation to monetary integration, which should lead to the creation of a single currency, the Euro [12].

However, during the Maastricht Treaty negotiationsthat established the Economic and Monetary UnionGermany was able to impose its preferences regarding the future shape of the single currency. Among those preferences there was the no bailout clause of indebted countries, and later a centralized supervision on fiscal policy that allowed for sanctioning the Euro countries with large budget deficits.

The outbreak of the Greek sovereign debt crisis uncovered the structural weaknesses of the Euro system, namely the absence of stability mechanisms to support countries in financial need. Despite the risk of contagion to other Euro countries, in a first moment northern States preferred to stress the need for the affected nations to take severe austerity plans [13]. Behind this perspective was the well-known stance that deficit countries should bear its own costs of adjustment, otherwise there would be risk of moral hazard.

Overtime, Euro crisis management mixed the princeples of increased centralized fiscal policy control-from the six pack to the Fiscal Treaty-with growing European responsibility that allowed for the creation of current bailout mechanisms. Nevertheless, the balance between centralized control and European liability clearly 
benefited the former, which prevented the Euro countries to establish the much needed firewalls that could deter financial speculators.

Moreover, the Euro crisis was a hard proof for the political authority of European supranational institutions. Both the Commission and the European Parliament were unable to counter the almost absolute role that the European Council played since the eruption of the crisis in the field of European economic governance. Besides, the political process tend to be ruled by major European nations, which means that small and medium Member States are less capable to voice their concerns and protect their interests than they used to be.

Twenty years after the signing of the Maastricht Treaty, which established the legal framework for the creation of the European single currency, Germany seems to take the lead over the European Union political process, in the sense that it is the only country being able to impose its own views and preferences within the European decision-making. This situation could turn to be the utmost irony of the Euro history if one recalls that with Monetary Union France wanted them to give up the Deutsch mark in order to prevent a sort of Germanized Europe.

\section{REFERENCES}

[1] L. Tsoukalis, “The New European Economy Revisited,” Oxford University Press, Oxford, 2003.

[2] D. W. Urwin, “The Community of Europe: A History of European Integration since 1945,” 2nd Edition, Longman, London, 1997.

[3] A. Moravcsik, "The Choice for Europe: Social Purpose and State Power from Messina to Maastricht," Cornell University Press, New York, 1998.

[4] T. Padoa-Schioppa, "The Road to Monetary Union in Europe: The Emperor, the Kings, and the Genies,” Clar- endon Press, Oxford, 1994.

[5] L. Tsoukalis, "Economic and Monetary Union,” In: H. Wallace and W. Wallace, Eds., Policy-Making in the European Union, 3rd Edition, Oxford University Press, Oxford, 1997, pp. 279-299.

[6] K. R. McNamara, "Economic and Monetary Union”, In: W. Wallace, H. Wallace and M. Pollack, Eds., PolicyMaking in the European Union, 5th Edition, Oxford University Press, Oxford, 2005, pp. 141-160.

[7] B. Marzinotto, A. Sapir and G. Wolff, "What Kind of Fiscal Union?” Bruegel Policy Brief, No. 6, 2011, pp. 1-8. http://www.bruegel.org/publications/publication-detail/pu blication/646-what-kind-of-fiscal-union/

[8] J. Pisani-Ferry, "The Euro Crisis and the New Impossible Trinity,” Bruegel Policy Contribution, No. 1, 2012, pp. 1-16.

http://www.bruegel.org/publications/publication-detail/pu blication/674-the-euro-crisis-and-the-new-impossible-trin ity/

[9] M. Feldstein, "The Failure of the Euro," Foreign Affairs, Vol. 91, No. 1, 2012, pp. 105-116.

[10] H. Schmidt, “Deutschland in Und Mit Europa,” 2011. http://www.spd.de/aktuelles/Pressemitteilungen/21498/20 111204_rede_helmut_schmidt.html

[11] M. Leonard, "Four Scenarios for the Reinvention of Europe,” European Council on Foreign Relations, London, 2011, pp. 1-16. http://www.ecfr.eu/page/-/ECFR43_REINVENTION_OF _EUROPE_ESSAY_AW1.pdf

[12] M. Auerback, “A 'United States of Europe' or Full Exit from the Euro?” International Journal of Political Economy, Vol. 39, No. 4, 2011, pp. 87-102. doi:10.2753/IJP0891-1916390404

[13] D. B. Papadimitriou and L. R. Wray, "Euroland in Crisis as the Global Meltdown Picks up Speed-Working-Paper No. 693,” Levy Economics Institute of Bard College, New York, 2011. http://www.levyinstitute.org/pubs/wp_693.pdf 